\title{
Obamacare
}

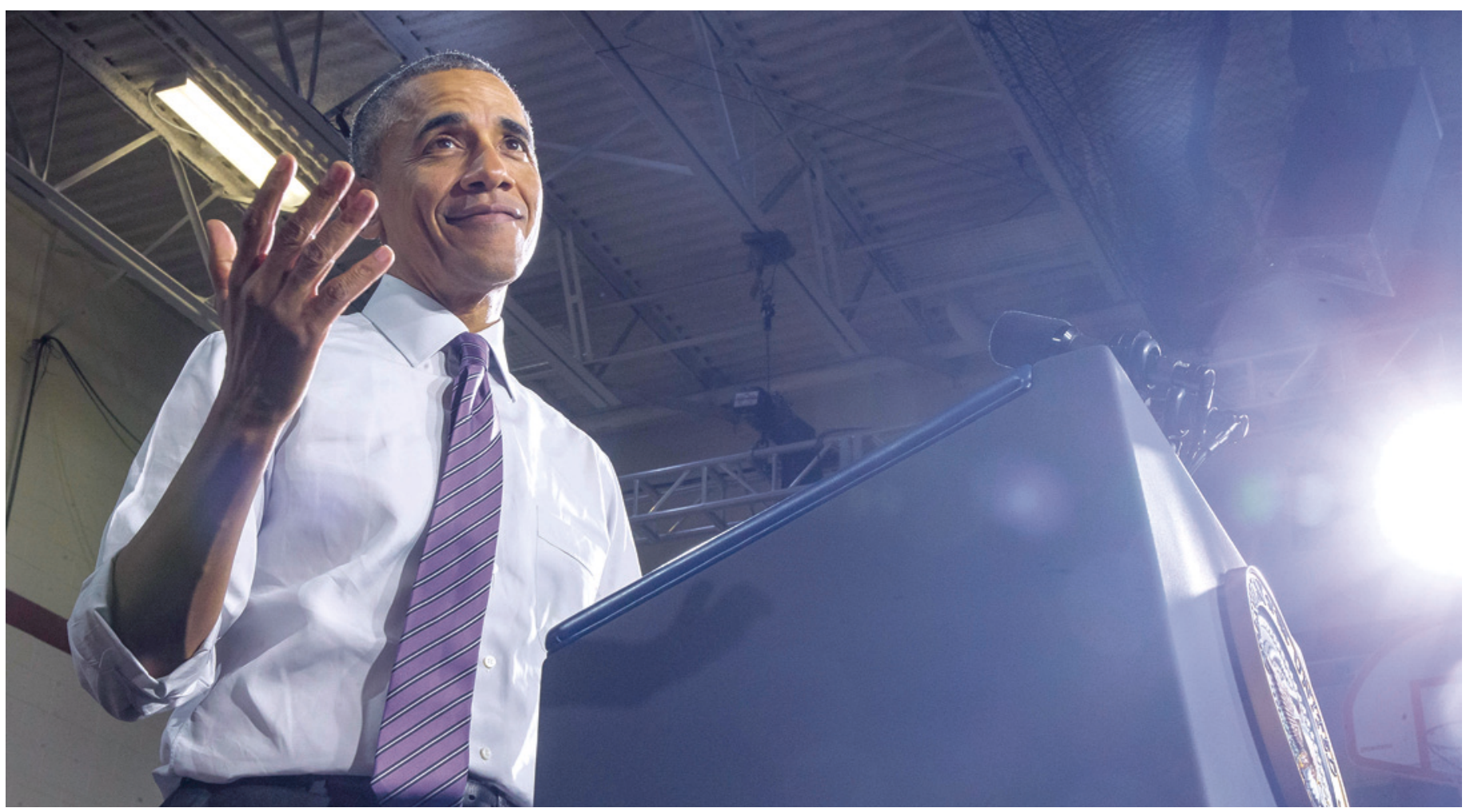

President Barack Obama på et folkemøte i Milwaukee. Foto: Zach Gibson/The New York Times/NTB scanpix

I august i år sto det en vitenskapelig artikkel om den amerikanske helsetjenestereformen på trykk i JAMA (1). Det spesielle med den er ikke temaet, men forfatteren - den er skrevet av Barack Obama. At en sittende president skriver $\mathrm{i}$ et vitenskapelig tidsskrift, er i seg selv uvanlig - og her skriver han altså en tilsynelatende vitenskapelig artikkel om en politisk reform han selv har iverksatt.

«Historien vil nesten sikkert rangere helsetjenestereformen som det viktigste Obama fikk gjennomført», skriver New York Times i en kommentar (2) - for øvrig kalt Obamacare's kindest critic. Og Obama selv er ganske fornøyd. Et sentralt mål var å få ned antallet mennesker uten helseforsikring for å sikre at alle får helsehjelp uten at det innebærer økonomisk katastrofe. Andelen uten helseforsikring er klart gått ned (fra 16\% til 9,1\%), noe som også betyr at den private helsegjelden er redusert. Likevel, skriver han, er det mye som kan gjøres bedre. Artikkelen ender med noen forslag.

Beskrivelsen av reformens virkninger er det som mest minner om en vitenskapelig artikkel, den underbygges av statistikk fra pålitelige kilder. I en kommentar i $B M J(3)$, som særlig dreier seg om artikkelens viten- skapelige status, spørres det imidlertid hvorfor redaksjonen i $J A M A$ valgte «rigorous internal review» i stedet for ekstern vurdering, noe som ville gjort oss bedre i stand til å vurdere kvaliteten på beskrivelsen og kildebruken.

Artikkelen for øvrig skiller seg fra det vitenskapelige formatet ved at diskusjonen er rammet inn som «mine grunner til å gjennomføre reformen», «mine erfaringer under arbeidet » og «dette er de store utfordringene fremover». Dermed blir det også en sterkt politisk tekst. Republikaneres kroniske trenering av alle forslag og legemiddelindustriens overdrevne jakt på profitt fremheves som to av de store utfordringene i det videre arbeidet for å sikre at alle får helsehjelp når de trenger det.

Obama anbefaler mindre «hyperpartisanship» - politisk motstand som prinsipp, i motsetning til saklig begrunnelse - og sier at industrien ikke må glemme «the sense of mission in health care that brought us an affordable polio vaccine and widely available penicillin». Og han anbefaler pragmatisme. Mange i USA har ønsket et system som ligner det engelske National Health Service (NHS), med én eier i stedet for mange konkurrerende tilbydere og betalere.
«Pragmatisme for realisme» er Obamas argument - politikk er det muliges kunst.

Politikk er også retorikk. Sjelden avsluttes en presumptivt vitenskapelig tekst slik: «As this progress with health care reform in the United States demonstrates, faith in responsibility, belief in opportunity and ability to unite around common values are what makes this nation great.»

Ingen andre land bruker så mye på helsetjenester som USA. Og kvaliteten på helsetjenestene spenner fra det beste $\mathrm{i}$ verden til under pari. Ineffektiv ressursbruk og sosial skjevfordeling er de største utfordringene. Kanskje har New York Times rett når de skriver at helsereformen er det viktigste Obama gjennomførte. $43 \%$ nedgang i antall mennesker uten forsikring er i hvert fall et vesentlig skritt i riktig retning. Så gjenstår det å se hva fremtiden vil bringe - etter 8 . november.

\section{Berit Bringedal}

LEFO - Legeforskningsinstituttet

Litteratur

1. Obama B. United States Health Care Reform: Progress to Date and Next Steps. JAMA 2016; 316: 525-32.

2. Obamacare's Kindest Critic. New York Times 16.7.2016.

3. Kamerow D. Obama turns his hand to health policy analysis. BMJ 2016; 354: i4442. 